\title{
BSMI AND TAQI POLYMORPHISMS IN VITAMIN D RECEPTOR GENE OF TYPE 2 DIABETES MELLITUS PATIENTS FROM NORTH INDIA
}

\author{
NANCY TANEJA ${ }^{1 *}$, RAJESH KHADGAWAT ${ }^{2}$, SHALINI MANI ${ }^{1}$ \\ ${ }^{1}$ Department of Biotechnology, Jaypee Institute of Information Technology, Noida, Uttar Pradesh, India. ${ }^{2}$ Department of Endocrinology, \\ All India Institute of Medical Sciences, New Delhi, India. Email: shalini.mani@jiit.ac.in
}

Received: 24 August 2016, Revised and Accepted: 29 August 2016

\section{ABSTRACT}

Objective: Polymorphisms in vitamin D receptor (VDR) genes are known to be linked with different metabolic diseases including Type 2 diabetes mellitus (T2DM) also. However, the association of these polymorphisms is not much explored for the Indian population. To determine the prevalence of BsmI and TaqI polymorphism in VDR gene of T2DM patients from North India.

Methods: Blood samples were obtained from 100 well-characterized T2DM patients and 100 healthy controls. Genomic DNA was isolated from blood samples and using polymerase chain reaction/restriction fragment length polymorphism based method, the presence of these polymorphisms was investigated in these samples. The data were statistically analyzed using SPSS 21.0 software.

Results: For TaqI polymorphism, both the wild type (TT) and heterozygous (TC) genotype showed a significant difference between patients and controls ( $\mathrm{p}=0.023$ and $\mathrm{p}<0.001$, respectively). Whereas, the frequency of CC genotype was not significantly different among these groups ( $\mathrm{p}=0.506$ ). For BsmI polymorphism also, the frequency of wild type (GG) and heterozygous (GA) genotype was significantly different in patients and controls $(\mathrm{p}=0.027$ and $\mathrm{p}=0.001)$, respectively. However, the frequency of AA genotype was not of statistical significance in patients $(\mathrm{p}=0.071)$.

Conclusions: The mutant alleles of TaqI and BsmI polymorphisms are known to be associated with different metabolic diseases, including diabetes too. In our study also, there is a significant difference between the frequency of wild type and heterozygous genotype for these polymorphisms. This suggests that BsmI and TaqI polymorphisms may be associated with T2DM patients.

Keywords: Type 2 diabetes mellitus, Polymorphism, Vitamin D receptor, Patient, Control, Restriction fragment length polymorphism.

(C) 2016 The Authors. Published by Innovare Academic Sciences Pvt Ltd. This is an open access article under the CC BY license (http://creativecommons. org/licenses/by/4. 0/) DOI: http://dx.doi.org/10.22159/ajpcr.2016.v9s3.14875

\section{INTRODUCTION}

Type 2 diabetes mellitus (T2DM) is one of the most prevalent lifestyle diseases, which is characterized by the high blood glucose levels resulting from defects in insulin action. It usually initiates with insulin resistance, a disorder in which the cells do not respond to insulin properly and increases the risks of many other diseases [1]. According to the International Diabetes Federation by 2035, worldwide the number of T2DM patients is estimated to exceed more than 600 million. India is known as a capital of diabetes, shelter to more than 63 million people suffering from diabetes, expected to increase to 100 million by 2030 [2]. This increase in the T2DM patient is matter of serious concern. Being a complex disease, T2DM is known to be caused by a large number of environmental and genetic factors too. The role of vitamin $\mathrm{D}$ in the pathogenesis and prevention of DM has sparked widespread interest. Apart from its classical role in $\mathrm{Ca}^{++}$homeostasis, vitamin D also regulates insulin secretion from beta cells and its action on various target cells too [3-8]. All the vitamin D-mediated signaling is entirely dependent on its binding with the vitamin D receptors (VDR), which are present on the surface of the nuclear membrane. VDR, after binding with vitamin $\mathrm{D}$, acts as active transcription factors, which controls the expression of approximately 200 genes including insulin too. Hence, variations/mutation in VDR gene is known to affect the insulin level, leading to diabetes [9-11].

Several polymorphisms in VDR gene have been reported to be associated with various metabolic diseases [12-15]. From last decade, these polymorphisms are also reported in different diabetic populations [16] It has been hypothesized that VDR polymorphisms may influence both the risk of occurrence of diabetes and its prognosis too [17]. Out of all the reported VDR polymorphisms which are known to be associated with diabetes, four allelic variants have been commonly identified and described in great detail. These polymorphisms are rs731236
(TaqI), rs1544410 (BsmI), rs7975232 (ApaI), and rs10735810 (Fok1). These four single nucleotide polymorphisms were identified using TaqI, BsmI, ApaI, and FokI restriction enzymes, respectively. The TaqI polymorphism is located at exon 9 (T65058C bp), codon 352. Although this is a synonymous change, it is reported to be associated with lower circulating levels of active vitamin D3 [18-20]. BsmI is present in intron $8(63980 \mathrm{bp})$ at the $3^{\prime}$ end, and being an intronic polymorphism, do not change the amino acid sequence of the encoded protein, but they may affect the expression of VDR gene by regulating the stability of mRNA [21]. Different research groups observed that both these polymorphisms, either independently or together, are associated with insulin resistance and increase in the fasting glucose levels $[22,23]$ In contrary, Ye et al., Malecki et al., and Cyganek et al. examined that there was no significant association of these polymorphisms with T2DM [24-26]. The status of association of these polymorphisms is also not very clear in context to the Indian population as there are very few reports available which highlight their association with diabetic phenotype in India [27]. Hence, the present work aims at investigating the association of the TaqI and BsmI polymorphism of VDR gene in T2DM patients from North India.

\section{METHODS}

\section{Study population}

A total of 100 T2DM patients and respective 100 controls were selected for the study. All the participants were recruited from All Indian Institute of Medical Sciences (AIIMS), New Delhi, India. These participants were between the ages of 35 and 55 years, non-smokers and belonged to the same ethnic group. T2DM patients were diagnosed on the basis of ADA Guidelines (2012). Individuals with fasting glucose $\geq 126 \mathrm{mg} / \mathrm{dl}$ and postprandial glucose $\geq 200 \mathrm{mg} / \mathrm{dl}$ were classified as diabetic. However, healthy controls with no metabolic disease were considered as controls. The present study was approved by the ethical committee of AIIMS, 
New Delhi, India. The blood samples and clinical details were collected after taking the informed consent from all the participants.

\section{Genomic DNA extraction}

About $2 \mathrm{ml}$ of the blood sample was collected in ethylenediamine tetra acetic acid coated BD Vacutainer and extraction of total genomic DNA was performed using the standard protocol of salting out method [28]. DNA extracted was stored at $-80^{\circ} \mathrm{C}$ for further experiments.

\section{Genotyping/polymerase chain reaction (PCR)-restriction} fragment length polymorphism (RFLP)

To do genotyping by RFLP, a region of 745 and 155 bp carrying the restriction sites of TaqI and BsmI, was amplified by PCR. The specific PCR products were digested with TaqI and BsmI restriction enzyme. For amplification of VDR gene segments containing TaqI and BsmI restriction sites, the published primers were used (Table 1).

PCR amplification was carried out using the Biorad DNA Engine Thermal Cycler (PTC0200), the reaction mix was prepared using 50 ng of DNA, 10 pmol of both the forward (F) and reverse (R) primers (Sigma-Aldrich), $2 \mathrm{mM}$ of dNTP's (Sigma-Aldrich), 0.5U Taq polymerase (Sigma-Aldrich), and nuclease-free water was used to make volume to $20 \mu \mathrm{l}$. PCR conditions were initial denaturation at $95^{\circ} \mathrm{C}$ for 5 minutes; 30 cycles of denaturation at $95^{\circ} \mathrm{C}$ for 1 minute; annealing at $68^{\circ} \mathrm{C} / 63^{\circ} \mathrm{C}(\mathrm{TaqI} / \mathrm{BsmI})$ for 1 minute; extension at $72^{\circ} \mathrm{C}$ for 1 minute followed by final extension at $72^{\circ} \mathrm{C}$ for 5 minutes. The PCR product of 745 and $155 \mathrm{bp}$ was digested with 10 unit of each $\mathrm{TaqI}\left(65^{\circ} \mathrm{C}\right.$ for $4 \mathrm{hrs}$, Thermo Scientific) and BsmI $\left(37^{\circ} \mathrm{C}\right.$ for $4 \mathrm{hrs}$, Thermo Scientific) restriction enzyme, respectively. These digested products were then resolved in $4 \%$ agarose gel stained with ethidium bromide using gel electrophoresis system at $100 \mathrm{~V}$ for 1-2 hrs. The gel was visualized under ultraviolet light using BioRad gel doc system.

As per the different genotypes for each polymorphism, the expected size of fragments obtained after digestion with TaqI and BsmI are mentioned in Table 1.

\section{Statistical analysis}

The statistical analysis was performed using a commercially available software program (SPSS 21.0, SPSS Inc., Chicago, Illinois, USA). The difference in allelic and genotypic frequencies was compared, using the Chi-square $\left(\chi^{2}\right)$ tests. Results were analyzed by calculating the $\mathrm{p}$ value and 95 confidence intervals. $p$ values with $<0.05$ were considered to be statistical significant.

\section{RESULTS}

\section{General characteristics of study population}

The mean age of T2DM patients was $46.8 \pm 11.33$ years, and it was observed to be $39.34 \pm 11.12$ years for the control group. Among all the T2DM patients, the average fasting glucose level was found to be $158.25 \pm 48.85 \mathrm{mg} / \mathrm{dl}$, whereas postprandial plasma glucose level was $235.57 \pm 86.0 \mathrm{mg} / \mathrm{dl}$.

Distribution of TaqI and BsmI polymorphisms in VDR gene For TaqI polymorphism, genotype frequencies were TT $(36 \%)$, TC (54\%), and CC (10\%) in patients and TT (50\%), TC (37\%), and CC
$(13 \%)$ in controls. It indicated that out of 3 genotypes, the heterozygous genotype was the most common in patients. On the other hand, the wild type genotype was the most common type in control. In both the groups, the mutant profile was less prevalent (Table 2).

As a result of statistical analysis, the frequency of TT and TC genotype of TaqI polymorphism showed a significant difference between patients and controls ( $p=0.023$ and $p<0.001$, respectively). Whereas the frequency of mutated profile (CC) was not significantly different among these two groups, with $\chi^{2}=0.442, p=0.506$ (Table 2). After the comparison of the frequency of mutant allele (C), there was no significant difference observed between patients and controls $\left(\chi^{2}=1.100, p=0.294\right)$ (Table 3).

Analysis of different genotypes of BsmI revealed that frequency of genotypes was GG (20\%), GA (56\%), and AA $(24 \%)$ in patients and GG (9\%), GA (77\%), and AA (14\%) for controls. Here again, the heterozygous genotype was most common in both the groups, but its frequency was higher in controls. Unlike TaqI, the least common genotype in both groups was found to be wild type genotype (Table 4).

As similar to TaqI polymorphism, the frequency of wild type (GG) and heterozygous genotype (GA) of BsmI was also found to be significantly different in patients and controls $\left(\chi^{2}=4.88, p=0.027\right.$ and $\chi^{2}=10.945$, $\mathrm{p}=0.001$ ). However, the frequency of mutated profile (AA) was not different among these two groups of individuals $\left(\chi^{2}=3.249, p=0.071\right)$ (Table 4). Moreover, allelic frequency of mutant allele (A) was also found to be same in patients and controls $\left(\chi^{2}=0.020, p=0.887\right)$ (Table 5).

\section{DISCUSSION}

The importance of studying polymorphisms in the VDR gene initially emerges due to ethnic differences among different populations [18-20,31,32]. However, later it was also found to be associated with different metabolic diseases including diabetes [12-14,21-26]. As VDR gene is expressed in different types of tissues including pancreatic $\beta$-cells and adipocytes $[33,34]$, which supports the idea that VDR polymorphisms possibly affects the insulin secretion and glucose metabolism $[35,36]$.

In recent years, the relevance of VDR polymorphism has been investigated by a large number of studies in T2DM patients from different populations. The observations of different studies were not same. Most of the VDR gene polymorphism-related studies suggested a significant association between heterozygous and/or mutant genotype with different clinical parameters of diabetes such as glucose levels, obesity, and insulin level. For example, the study of BsmI polymorphism in T2DM patients done by Ortlepp et al. suggests a significant association of BsmI with fasting glucose levels of 1539 T2DM patients ( $\mathrm{p}=0.018$ ) [22]. Similarly, Oh et al. investigated BsmI polymorphisms and found a significant association with insulin levels of the 1545 T2DM patients, $\mathrm{p}<0.05$ [36]. A study by Al-Daghri et al. found that TaqI and BsmI polymorphisms are significantly associated with T2DM $\mathrm{n}=627$, $\mathrm{p}=0.033$ [37]. On the similar lines, Ogunkolade et al. found a significant association of TaqI and insulin secretion in 143 Bangladeshi Asians $(p<0.001)$ [32]. However, on the other hand, there are studies which contradict the same. For instance, the study by Bid et al., 2009,

Table 1: Details of primer sequences and fragment lengths obtained after digestion of PCR products with TaqI and BsmI restriction enzymes

\begin{tabular}{|c|c|c|c|c|c|c|c|}
\hline SNP & Position (bp) & SNP ID & Base change & Primer sequence & Annealing & $\begin{array}{l}\text { Amplicon } \\
\text { length (bp) }\end{array}$ & $\begin{array}{l}\text { Genotype/RFLP } \\
\text { product }\end{array}$ \\
\hline TaqI & Exon 9 (65058) & rs731236 & $\mathrm{T} / \mathrm{C}$ & $\begin{array}{l}\text { F5'CAGAGCATGGACAGGGAGCAA-3' } \\
\text { R5'GCAACTCCTCATGGCTGAGGTCTC-3' [29] }\end{array}$ & $68^{\circ} \mathrm{C}$ & 745 & $\begin{array}{l}\mathrm{TT} / 494,251 \\
\mathrm{CC} / 293,251,201\end{array}$ \\
\hline BsmI & Intron 8 (63980) & rs1544410 & $\mathrm{G} / \mathrm{A}$ & $\begin{array}{l}\text { F-5'GTGTGCAGGCGATTCGTA -3' } \\
\text { R5'TACCCTGCCCGCAAGAAA -3'[30] }\end{array}$ & $63^{\circ} \mathrm{C}$ & 155 & $\begin{array}{l}\mathrm{GG} / 80,70, \mathrm{AA} / 155 \\
\mathrm{GA} / 155,80,70\end{array}$ \\
\hline
\end{tabular}

PCR: Polymerase chain reaction, SNP: Single nucleotide polymorphisms, RFLP: Restriction fragment length polymorphism 
Table 2: Distribution of TaqI polymorphism in T2DM patients and respective control

\begin{tabular}{lllll}
\hline Genotype & $\begin{array}{l}\text { Patients } \\
(\mathbf{N = 1 0 0 )} \%\end{array}$ & $\begin{array}{l}\text { Controls } \\
(\mathbf{N}=100)\end{array}$ & $\chi^{2}$ & p value \\
& $36(36)$ & $50(50)$ & 5.195 & $0.023^{*}$ \\
TT (wild) & $54(54)$ & $37(37)$ & 37.72 & $<0.001^{* *}$ \\
TC (heterozygous mutant) & $10(10)$ & $13(13)$ & 0.442 & 0.506 \\
\hline CC (mutant) & 10 &
\end{tabular}

Statistical evaluation was made using the Chi-square test, ${ }^{*} \mathrm{p}<0.05,{ }^{* *} \mathrm{p}<0.01$. T2DM: Type 2 diabetes mellitus

Table 3: Comparison of allelic frequencies of TaqI in T2DM patients and control

\begin{tabular}{lllll}
\hline Allele & Patients (\%) & Controls (\%) & $\chi^{2}$ & p value \\
\hline $\mathrm{T}$ & $126(63)$ & $138(69)$ & 1.100 & 0.294 \\
$\mathrm{C}$ & $74(37)$ & $62(31)$ & & \\
\hline
\end{tabular}

Statistical evaluation was made using the Chi-square test. T2DM: Type 2 diabetes mellitus

Table 4: Distribution of BsmI polymorphism in T2DM patients and respective control

\begin{tabular}{lllll}
\hline Genotype & $\begin{array}{l}\text { Patients } \\
(\mathbf{N = 1 0 0 )} \%\end{array}$ & $\begin{array}{l}\text { Controls } \\
(\mathbf{N = 1 0 0 )} \%\end{array}$ & $\chi^{2}$ & p value \\
& $20(20)$ & $9(9)$ & 4.880 & $0.027^{*}$ \\
GG (wild) & $56(56)$ & $77(77)$ & 10.945 & $0.001^{* *}$ \\
GA (heterozygous mutant) & $24(24)$ & $14(14)$ & 3.249 & 0.071 \\
\hline AA (mutant) & 24.07 \\
\hline
\end{tabular}

Statistical evaluation was made using the Chi-square test, ${ }^{*} \mathrm{p}<0.05,{ }^{* *} \mathrm{p}<0.01$. T2DM: Type 2 diabetes mellitus

Table 5: Comparison of allelic frequencies of BsmI in T2DM patients and control

\begin{tabular}{lllll}
\hline Allele & Patients (\%) & Controls (\%) & $\chi^{2}$ & p value \\
\hline $\mathrm{G}$ & $96(48)$ & $92(46)$ & 0.020 & 0.887 \\
$\mathrm{~A}$ & $104(52)$ & $108(54)$ & & \\
\hline
\end{tabular}

Statistical evaluation was made using the Chi-square test. T2DM: Type 2 diabetes mellitus

observed a non-significant association between any of common VDR polymorphisms (FokI, BsmI, and TaqI) and risk of T2DM [27]. Malecki et al. also studied VDR polymorphisms (Fok1, ApaI, BsmI, and TaqI) in Polish population and showed no association of these polymorphisms with T2DM [25]. Cyganek et al. did the same study in 267 T2DM patients of Poland, and there was no association found with the T2DM [26]. In 1998, Hitman et al. studied ApaI, BsmI, and TaqI in 164 T2DM patients and observed a non-significant association of BsmI and TaqI with T2DM [17].

In context to the Indian population, there is scarcity of the data which may support either of the view for VDR polymorphisms and its association with diabetes. Thus, in the current study, we have analyzed two common VDR gene polymorphisms; TaqI and BsmI in T2DM patients from North India. TaqI polymorphism is a silent substitution thus does not account for an amino acid change in VDR protein [32] However, the wild type TT genotype of TaqI polymorphism is known to be associated with high copy number of VDR mRNA [17,32]. Hence, it may be hypothesized that the patients lacking wild genotype may have low copies of VDR gene transcripts which may probably affect level of VDR protein, and hence, the glucose metabolism too. In our study, the patient group had significantly a low number of wild type genotype TT, and it was found in only $36 \%$ of patients as compared to $50 \%$ of controls. The heterozygous TC genotype of TaqI polymorphism also shows a significant difference between T2DM patients and controls, further highlighting the possible role of mutant allele in determining the copy number of VDR gene transcript. The mutant profile (CC) of TaqI polymorphism was equally distributed in both the groups of individuals.

$B s m I$ is an intronic polymorphism and proposed to affect the stability of VDR transcript [38]. It has also been demonstrated that an association exists between the BsmI polymorphisms of VDR gene and low insulin secretion in T2DM patients [17]. The study conducted by Speer et al. also showed that there is a link between heterozygous genotype of BsmI polymorphisms and T2DM in the Caucasian population [39]. In the similar context, we have also observed that the frequency of heterozygous GA genotype was significantly different among patients and controls $(p=0.001)$. As similar to TaqI, we observed the significant difference between the frequency of wild type genotype between patients and controls, but surprisingly, the wild type genotype was higher in patients and heterozygous genotype was higher in controls. In addition, the mutant profile showed no difference between two groups of individuals as similar to TaqI data.

Comparison of frequency of mutant allele for both the polymorphisms indicated that there is no significant difference between patients and controls, however, to validate the same a large scale study design is required

\section{CONCLUSION}

Both these polymorphisms are proposed to influence the transcription and/or stability of mRNA of VDR gene. Hence, based on our study and results from published literature, it can be proposed that TaqI and BsmI VDR polymorphisms may be associated with T2DM. Moreover, VDR signaling is also known to be important for insulin secretion and its action on the target cell. Hence, these polymorphisms may be suggested to be associated with altered insulin secretion and/or action, further contributing to the development of T2DM.

Although these two polymorphisms are not the only polymorphisms of VDR gene, known to be associated with T2DM, we propose to study the role of other VDR polymorphisms in these patients.

\section{ACKNOWLEDGMENT}

This work was supported and funded by the Jaypee Institute of information Technology, Noida, India.

\section{REFERENCES}

1. American Diabetes Association. Diagnosis and classification of diabetes mellitus. Diabetes Care 2004;27 Suppl 1:S5-10.

2. Kaveeshwar SA, Cornwall J. The current state of diabetes mellitus in India. Australas Med J 2014;7(1):45-8.

3. Chantal M, Conny G, Annapaula G, Roger B. Vitamin D and diabetes. Diabetologia 2005;48(7):1247-57

4. Takiishi T, Gysemans C, Bouillon R, Mathieu C. Vitamin D and diabetes. Endocrinol Metab Clin North Am 2010;39(2):419-46.

5. Mitri J, Pittas AG. Vitamin D and diabetes. Endocrinol Metab Clin North Am 2014;43(1):205-32.

6. Palomer X, González-Clemente JM, Blanco-Vaca F, Mauricio D. Role of vitamin $\mathrm{D}$ in the pathogenesis of Type 2 diabetes mellitus. Diabetes Obes Metab 2008;10(3):185-97.

7. Venkatesh G, Jayprakash A, Swathi KS. The effect of sun light exposure on prediabetic patients in south Indian population. Int J Pharm Pharm Sci 2014;6(11):107-10

8. Mallayasamy M, David HA, Pandian PR. Comparison of angiotensin receptor blocker alone and in combination with vitamin $\mathrm{D}$ analogue in reducing proteinuria in diabetic nephropathy patients. Int J Pharm Pharm Sci 2014;6(8):201-4.

9. Hossein-nezhad A, Spira A, Holick MF. Influence of vitamin D status and vitamin D3 supplementation on genome wide expression of white blood cells: A randomized double-blind clinical trial. PLoS One 2013;8(3):e58725.

10. Montecino M, Stein GS, Stein JL, Lian JB, van Wijnen AJ, Carvallo L, et al. Vitamin D control of gene expression: Temporal and spatia parameters for organization of the regulatory machinery. Crit Rev 
Eukaryot Gene Expr 2008;18(2):163-72

11. Tarroni P, Villa I, Mrak E, Zolezzi F, Mattioli M, Gattuso C, et al. Microarray analysis of $1,25(\mathrm{OH}) 2 \mathrm{D} 3$ regulated gene expression in human primary osteoblasts. J Cell Biochem 2012;113(2):640-9.

12. McCullough ML, Stevens VL, Diver WR, Feigelson HS, Rodriguez C, Bostick RM, et al. Vitamin D pathway gene polymorphisms, diet, and risk of postmenopausal breast cancer: A nested case-control study. Breast Cancer Res 2007;9(1):R9.

13. Cicek MS, Liu X, Schumacher FR, Casey G, Witte JS. Vitamin D receptor genotypes/haplotypes and prostate cancer risk. Cancer Epidemiol Biomarkers Prev 2006;15(12):2549-52

14. Gao L, Tao Y, Zhang L, Jin Q. Vitamin D receptor genetic polymorphisms and tuberculosis: Updated systematic review and meta-analysis. Int J Tuberc Lung Dis 2010;14(1):15-23.

15. Wang TJ, Zhang F, Richards JB, Kestenbaum B, van Meurs JB, Berry D, et al. Common genetic determinants of vitamin D insufficiency: A genome-wide association study. Lancet 2010;376(3736):180-8.

16. Györffy B, Vásárhelyi B, Krikovszky D, Madácsy L, Tordai A, Tulassay $\mathrm{T}$, et al. Gender-specific association of vitamin $\mathrm{D}$ receptor polymorphism combinations with Type 1 diabetes mellitus. Eur $\mathrm{J}$ Endocrinol 2002;147(6):803-8.

17. Hitman GA, Mannan N, McDermott MF, Aganna E, Ogunkolade BW, Hales CN, et al. Vitamin D receptor gene polymorphisms influence insulin secretion in Bangladeshi Asians. Diabetes 1998;47(4):688-90.

18. Morrison NA, Qi JC, Tokita A, Kelly PJ, Crofts L, Nguyen TV, et al. Prediction of bone density from vitamin D receptor alleles. Nature 1994;367(6460):284-7.

19. Hustmyer FG, DeLuca HF, Peacock M. ApaI, BsmI, EcoRV and TaqI polymorphisms at the human vitamin D receptor gene locus in Caucasians, blacks and Asians. Hum Mol Genet 1993;2(4):487.

20. Ma J, Stampfer MJ, Gann PH, Hough HL, Giovannucci E, Kelsey KT, et al. Vitamin D receptor polymorphisms, circulating vitamin D metabolites, and risk of prostate cancer in United States physicians. Cancer Epidemiol Biomarkers Prev 1998;7(5):385-90.

21. Jurutka PW, Whitfield GK, Hsieh JC, Thompson PD, Haussler CA, Haussler MR. Molecular nature of the vitamin D receptor and its role in regulation of gene expression. Rev Endocr Metab Disord 2001;2(2):203-16.

22. Ortlepp JR, Metrikat J, Albrecht M, Von Korff A, Hanrath P, Hoffmann R. The vitamin D receptor gene variant and physical activity predicts fasting glucose levels in healthy young men. Diabet Med 2003;20(6):451-4.

23. Li L, Wu B, Liu JY, Yang LB. Vitamin D receptor gene polymorphisms and Type 2 diabetes: A meta-analysis. Arch Med Res 2013;44(3):235-41.

24. Ye WZ, Reis AF, Dubois-Laforgue D, Bellanné-Chantelot C, Timsit J, Velho G. Vitamin D receptor gene polymorphisms are associated with obesity in Type 2 diabetic subjects with early age of onset. Eur J Endocrinol 2001;145(2):181-6.

25. Malecki MT, Frey J, Moczulski D, Klupa T, Kozek E, Sieradzki J. Vitamin D receptor gene polymorphisms and association with Type 2 diabetes mellitus in a Polish population. Exp Clin Endocrinol Diabetes
2003;111(8):505-9

26. Cyganek K, Mirkiewicz-Sieradzka B, Malecki MT, Wolkow P, Skupien J, Bobrek J, et al. Clinical risk factors and the role of VDR gene polymorphisms in diabetic retinopathy in Polish Type 2 diabetes patients. Acta Diabetol 2006;43(4):114-9.

27. Bid HK, Konwar R, Aggarwal CG, Gautam S, Saxena M, Nayak VL, et al. Vitamin D receptor (FokI, BsmI and TaqI) gene polymorphisms and Type 2 diabetes mellitus: A North Indian study. Indian J Med Sci 2009;63(5):187-94

28. Miller SA, Dykes DD, Polesky HF. A simple salting out procedure for extracting DNA from human nucleated cells. Nucleic Acids Res 1988;16(3):1215.

29. Acikbas I, Sanli B, Tepeli E, Ergin S, Aktan S, Bagci H. Vitamin D receptor gene polymorphisms and haplotypes (Apa I, Bsm I, Fok I, Taq I) in Turkish psoriasis patients. Med Sci Monit 2012;18(11):CR661-6.

30. Naito M, Miyaki K, Naito T, Zhang L, Hoshi K, Hara A, et al. Association between vitamin $\mathrm{D}$ receptor gene haplotypes and chronic periodontitis among Japanese men. Int J Med Sci 2007;4(4):216-22.

31. Li H, Miao H, Lu Y, et al. Association between DNA polymorphism of human vitamin D receptor gene and Type 2 diabetes mellitus. China J Mod Med 2005;15:989-92.

32. Ogunkolade BW, Boucher BJ, Prahl JM, Bustin SA, Burrin JM, Noonan K, et al. Vitamin D receptor (VDR) mRNA and VDR protein levels in relation to vitamin D status, insulin secretory capacity, and VDR genotype in Bangladeshi Asians. Diabetes 2002;51(7):2294-300.

33. Reis AF, Hauache OM, Velho G. Vitamin D endocrine system and the genetic susceptibility to diabetes, obesity and vascular disease. A review of evidence. Diabetes Metab 2005;31:318-25.

34. Howard G, Nguyen T, Morrison N, Watanabe T, Sambrook P, Eisman J, et al. Genetic influences on bone density: Physiological correlates of vitamin D receptor gene alleles in premenopausal women. J Clin Endocrinol Metab 1995;80(9):2800-5

35. Shi H, Norman AW, Okamura WH, Sen A, Zemel MB. 1alpha,25-dihydroxyvitamin D3 modulates human adipocyte metabolism via nongenomic action. FASEB J 2001;15(14):2751-3.

36. Oh JY, Barrett-Connor E. Association between vitamin D receptor polymorphism and Type 2 diabetes or metabolic syndrome in community-dwelling older adults: The Rancho Bernardo study. Metabolism 2002;51(3):356-9.

37. Al-Daghri NM, Al-Attas OS, Alkharfy KM, Khan N, Mohammed AK, Vinodson B, et al. Association of VDR-gene variants with factors related to the metabolic syndrome, Type 2 diabetes and vitamin D deficiency. Gene 2014;542(2):129-33.

38. Morrison NA, Yeoman R, Kelly PJ, Eisman JA. Contribution of transacting factor alleles to normal physiological variability: Vitamin D receptor gene polymorphism and circulating osteocalcin. Proc Natl Acad Sci USA 1992;89(15):6665-9.

39. Speer G, Cseh K, Winkler G, Vargha P, Braun E, Takács I, et al. Vitamin D and estrogen receptor gene polymorphisms in Type 2 diabetes mellitus and in android type obesity. Eur $\mathrm{J}$ Endocrinol 2001;144(4):385-9. 